Иркутский государственный университет, г. Иркутск, Российская Федерация

Д. А. Мясников

Иркутский государственный университет, г. Иркутск, Российская Федерация

\title{
СТРУКТУРА И ЧИСЛЕННОСТЬ ПОЛИТИЧЕСКОЙ ССЫЛКИ ИРКУТСКОЙ ГУБЕРНИИ 1870-Х ГОДОВ
}

\begin{abstract}
АНнотАЦия. Статья посвящена малоисследованному сюжету в истории иркутской политической ссылки - установлению ее численности, половозрастного и социального состава, особенностей территориального размещения. В первую очередь авторы обращают внимание на состояние документальной базы своего исследования и приходят к выводу о ее сложной структуре и противоречивом характере. С одной стороны, многие материалы этого периода были утрачены в пожарах 1879 г., с другой, уцелевшие документы содержат лишь отрывочные и фрагментарные сведения. Тем не менее, с помощью сопоставления различного вида исторических источников удалось определить численность ссыльных, размещенных на территории губернии, их пол, происхождение, социальное положение, род занятий, национальность. Важное значение для дальнейшего изучения темы имеют и выводы авторов о постепенном преобладании в ссылке этого периода разночинцев над дворянскими революционерами и административно-ссыльных над сосланными по приговору суда. В рассматриваемое десятилетие среди ссыльных стали оформляться и места постоянного компактного проживания (будущие колонии), тяготевшие к крупным населенным пунктам, расположенным ближе к Иркутску.

кЛючЕВЫЕ СЛОВА. Политические ссыльные; Иркутская губерния; ссыльнопоселенцы; административно-ссыльные; колонии ссыльных.

ИНФОРМАЦИЯ О СТАТЬЕ. Дата поступления 22 апреля 2016 г.; дата принятия к печати 5 мая 2016 г.; дата онлайн-размещения 29 июля 2016 г.
\end{abstract}

\author{
A. A. Ivanov \\ Irkutsk State University, \\ Irkutsk, Russian Federation \\ D. A. Myasnikov \\ Irkutsk State University, \\ Irkutsk, Russian Federation
}

\section{STRUCTURE AND SIZE OF POLITICAL EXILE IN IRKUTSK PROVINCE IN THE 1870S}

\begin{abstract}
The article is devoted to the scantily studied plot in the history of the Irkutsk political exile - to identification of its size, sex-age and social composition, features of territorial placement. First of all, the authors pay attention to the condition of documentary base of their research and come to a conclusion about its difficult structure and contradictory character. On the one hand, many materials of this period had been lost in the fires of 1879 , on the other hand, the escaped documents contain only fractional and fragmentary information. Nevertheless, by comparing various types of historical sources it was made possible to determine the number of the exiled people placed on the province territory, their gender identities, origins, social status, occupations, nationalities. Of significant importance for further investigation of the topic are authors' conclusions about gradual prevalence in the exile of this period of the commoners over the noble revolutionaries and the administratively exiled people over the legally exiled ones. During the decade considered, the exiled began develop-
\end{abstract}

\section{Baikal Research Journal}


ing placements of full-time compact residence (future colonies) gravitating toward the large settlements located closer to Irkutsk.

KEYWORDS. Political exiles; Irkutsk Province; exiled settlers; administrative exiled; colonies of the exiled.

ARTICLE INFO. Received April 22, 2016; accepted May 5, 2016; available online July 29, 2016.

В 1870-е гг. противостояние государства и общества, как известно, значительно усилилось. Нелегальные группы «Народной Воли», действовавшие во всех крупных городах центра России, беспримерное по своим масштабам «хождение в народ» 1874 и 1875 гг., массовое увлечение молодежи революционной теорией и практикой движения, организованные студенческие выступления значительно увеличили и число подвергшихся репрессиям, осужденных военными или гражданскими судами, в том числе на каторгу или поселение. Соответственно, и иркутская политическая ссылка также выросла численно, существенно изменилась ее структура.

Цель настоящей статьи - установить количество политических ссыльных на территории Иркутской губернии в период 1870 -х гг., дать географию их размещения, социальный и половозрастной состав, выявить происхождение революционеров, определить основные виды трудовой занятости. В данной работе не рассматриваются участники польского национально-освободительного движения, история пребывания которых в указанном регионе после подавления январского 1863 г. восстания, является отдельной и самостоятельной темой исследования.

Несмотря на кажущееся обилие научной литературы по истории оппозиционного движения второй половины XIX в., в том числе и в Восточной Сибири, и в Иркутске в частности [1], определение числа революционеров, отбывавших здесь наказание, остается по-прежнему актуальной научной задачей. Ее решение затрудняется неудовлетворительным состоянием документальной базы. Дело в том, что основные архивы Иркутской экспедиции о ссыльных, полиции и жандармского полицейского управления были уничтожены городскими пожарами 1879 г., а многие документы, наработанные позже, в 1880-1900-х, были утрачены в лихолетье 1917-1920 гг. [2].

Пытаясь восполнить такой источниковый вакуум, историки советского периода определяли численность ссылки по иным документальным свидетельствам - газетам, воспоминаниям, дневникам, запискам современников, обрывкам официального делопроизводства. Такое «совмещение несовместимого» не могло не привести к появлению значительного расхождения в искомых итоговых цифрах. Например, Л. П. Рощевская, известный специалист этой темы, определяла число сибирских ссыльных в 35 чел. [3, с. 81, 98]. С. Ф. Коваль писал о «тысячах ссыльных революционеровдемократов России, Польши, Украины, Кавказа и других окраин», принявших участие «в сибирском общественном движении 1860-х годов» [4, с. 137], а В. Н. Дворянов вывел самую значительную цифру - 296 тыс. чел. [5, с. 93]. Как видим, данные специалистов сильно разнятся. В этом случае, на наш взгляд, единственно правильным подходом в определении количества политических ссыльных 1870-х гг. следует считать то, что оно не могло быть больше известного числа революционеров в целом, осужденных судом или высланных административно из Европейской России. Исходя из этого, обратимся к подсчетам Н. А. Троицкого, признанного специалиста данной темы. По его данным, с 1867 по 1878 г., в стране было организовано 63 судебных процесса, на которых осуждено 532 революционера, из них 92 отправлены на каторгу (в целом по стране) и $104-$ в сибирскую ссылку [6, с. 94].

В настоящих цифрах нет административно-ссыльных. Однако следует учесть, что административные высылки «неблагонадежных элементов» начались в основном со второй половины $1870-\mathrm{x}$ гг. и не могли, по нашему мнению, в общем количестве «се-

\section{Baikal Research Journal}

электронный научный журнал Байкальского государственного университета 
мидесятников» превышать числа сосланных по суду. Таким образом, вполне реальной итоговой цифрой, определяющей число сибирских ссыльных для периода 1870 -х гг., следует считать 200-250 чел. Заметим также, что эти данные хорошо сочетаются и с выводами А. Д. Марголиса, занимавшегося проблемами истории сибирской уголовной и политической ссылки в 1980-1990-х гг. Так, по сведениям ученого, использовавшего в своих подсчетах в основном источники из центральных архивов России, к 1880 г. в Сибири было сосредоточено «до 230» ссыльных всех категорий [7, с. 110].

Естественно, что в Иркутской губернии политических ссыльных должно было быть меньше. Для установления их числа обратимся к имеющимся разрозненным архивным источникам. Их несколько больше, чем в случае с 1860 гг., однако следует отметить, что все обнаруженные документы бедны информацией: кроме места причисления ссыльного в них отсутствуют какие-либо данные о человеке, его возрасте, семейном положении, занятиях. Понятно, что такие сведения не могут служить источником для широких обобщений и отражают прежде всего плохую организацию работы Иркутской экспедиции о ссыльных.

Данные документы страдают не только неполнотой, но и нередко носят противоречивый характер. Так, например, итоговая ведомость ссыльным по губернии за 1876 г. указывает на 42 государственных преступника, при этом в приводимом здесь же поименном списке всего 14 фамилий ${ }^{1}$. Есть в официальных материалах и сведения в целом по Восточной Сибири. Например, за 1877 г. указано 43 государственных преступника, из них 20 «иркутян» ${ }^{2}$. В большинстве обнаруженных документов количество политических ссыльных дается без деления на каторжан, поселенцев или административно-высланных. Место отбывания наказания (уезд, волость, село) также не значится. Например, в списке содержавшихся в пределах Иркутской губернии за тот же 1877 г. даны уже 43 чел., в списке на 16 июня 1878 г. - 38 чел., а в перечне от 27 февраля 1879 г. — вновь 43 фамилии ${ }^{3}$.

Несмотря на фрагментарность и отмеченные недостатки, архивные документы, на наш взгляд, достоверно передают существовавшее положение дел. Тем более, что эти цифры хорошо соотносятся с данными словаря «Деятели революционного движения в России». Этот исторический источник заслуживает хотя бы беглого упоминания. Биобиблиографический словарь был издан в 1927-1933 гг. Задуманный в качестве научно-справочного издания, посвященного героям-революционерам участникам борьбы с царизмом от А. Н. Радищева до социал-демократов и эсеров периода Первой русской революции, словарь состоит из десяти книг, содержащих, по нашим подсчетам, не менее 15 тыс. биографических справок, составленных в виде унифицированных карточек на «видных» и рядовых участников революционного движения. Сплошной анализ первых семи томов словаря «Деятели...» дал нам 319 биограмм революционеров, отбывавших наказание ссылкой в Иркутской губернии в 1860-1890-х гг. ${ }^{4}$ При этом 58 биограмм относятся к периоду 1870 -х гг. [8].

Приблизительно половина фамилий в списках Государственного архива Иркутской области и из словаря совпадают, половина - нет, следовательно, можно вполне обоснованно предположить, что на территории губернии в 1870 -е гг. находилось не менее 80-90 политических ссыльных (опять же, без учета ссыльных поляков), что, к слову, в три раза превосходит их численность за 1860 -е гг.

Анализ биограмм ссыльных дает и иную картину, чем была в предыдущий период. Если «шестидесятниками» были только мужчины, то в следующем десятиле-

${ }^{1}$ Государственный архив Иркутской области (ГАИО). Ф. 32. Оп. 1. Д. 151. Л. 30.

2 Там же. Ф. 24. Оп. Оц. Д. 931. Л. 1-10.

${ }^{3}$ Там же. Оп. Оц. Д. 931. Л. 297 ; Ф. 32. Оп. 1. Д. 346. Л. 4 ; Д. 300. Л. 8-14.

${ }_{4}^{4}$ Деятели революционного движения в России. От предшественников декабристов до падения царизма : биобиблиогр. слов. Том второй : Семидесятые годы. ВОПКиС, 1929-1932. Вып. I. 406 ст. ; вып. II. Ст. 408-836 ; вып. III. Ст. 838-1384 ; вып. IV. Ст. 1394-2156.

\section{Baikal Research Journal}

электронный научный журнал Байкальского государственного университета 
тии здесь появились и женщины - из 58 биограмм женских восемь, или 13,8 \% . Это немало и свидетельствует о стремительном увеличении роли женщин в общественной жизни страны, революционном движении в том числе. При этом среди женщин-ссыльных встречаются хорошо известные в нелегальном лагере имена, например: Ф. Н. Левандовская (Лянды) - пропагандистка-народница из Николаева, прибывшая в ссылку в 1879 г., водворенная в дер. Жданово Киренского уезда, затем в Тунке, с 1887 г. - в Киренске, с 1889 по 1906 г. жила в Иркутске, активная сотрудница «Восточного обозрения»; С. И. Новаковская (урожденная Гурович) - участница Казанской демонстрации, 1877 г. - с. Малышевское, Балаганск, 1885 г. - Верхоленск, за участие в протесте балаганских ссыльных сослана в Верхоянск, затем в Якутск, где и встретила октябрь 1917 г.; Н. Н. Смецкая (по мужу Шиманская) - за пропаганду среди уральских казаков в 1878 г. выслана, жила в Тунке, Иркутске, Балаганске, Якутске, Киренске; Е. Д. Субботина - привлекалась сразу по двум процессам - 193-х и 50-ти, в 1878 г. водворена в Тунке, высылалась в Верхоленск, жила в Иркутске, за помощь в организации побегов Брешковской, Ковальской и Богомолец наказывалась продлением срока ссылки; Л. Н. Фигнер (по мужу Стахевич), сестра В. Н. Фигнер - «за распространение преступных сочинений» в Иваново-Вознесенске и Москве сослана по суду, в 1877 г. жила в Урике, затем Иркутске, Усолье, участвовала в работе «Красного Креста» «Народной Воли», освобождена из-под надзора только в 1891 г. $^{5}$

Второй характерной особенностью ссылки «семидесятников» можно признать ее четкое разделение на две части - по приговору суда и административную. При этом благодаря стремлению правительства бороться с революционерами, не привлекая широкой общественности, административная ссылка настолько быстро набирала размах, что во второй половине рассматриваемого десятилетия уже превысила ссылку судебную. Так, в нашем случае, из 58 политических ссыльных губернии внесудебной расправе был подвергнут 31 чел., или 53,5 \% . Это яркое свидетельство того, что еще задолго до принятия Положения о мерах к охранению государственного порядка и общественного спокойствия (1881), внесудебная расправа широко практиковалась государством как один из инструментов борьбы с массовым радикальным движением.

У всех ссыльных удалось выявить национальность, сделав это, главным образом, по косвенным признакам. Оказалось, что 39 чел., или $67,3 \%$, были русскими, $20,7 \%$ - евреями, незначительное количество имелось малороссов, поляков, австрийцев, грузин. Как следует, настоящие показатели наглядно отражают ведущую роль прежде всего русской интеллигенции в борьбе за коренную демократизацию страны, а также свидетельствуют о крупных провалах национальной политики государства, результатом которой стал уход большой части еврейской молодежи в леворадикальное оппозиционное движение.

Вполне ожидаемые итоги дает и анализ происхождения ссыльных: к дворянскому сословию относилось далеко не подавляющее большинство революционеров лишь 45,5\%, много было мещан (40\%) и крестьян - 7,3 \%. Таким образом, есть

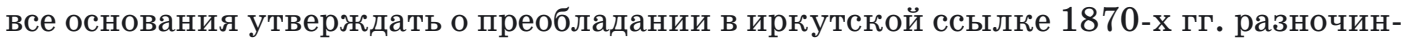
цев, что, в принципе, и не противоречит хрестоматийным выводам В. И. Ленина, отмечавшего разночинцев «начиная с Чернышевского и кончая героями "Народной воли" $[8$, с. 261] и о последовавшей затем эпохе, когда «дворяне уже составляют меньшую часть среди участников освободительного движения» [9, с. 398].

Впрочем, данные процентные показатели с успехом могут быть объяснимы и иначе, например, тем, что словарь «Деятели...» составлялся в середине 1920-х гг.

${ }^{5}$ Деятели революционного движения в России. Т. II, вып. ІІ. Стб. 749 ; вып. III. Стб. 1047 ; вып. IV. Стб. 1525, 1762, 1765, 1826.

\section{Baikal Research Journal}

электронный научный журнал Байкальского государственного университета 
уже при Советской власти, когда принадлежность к дворянскому сословию согласно Конституции страны лишала человека избирательных прав, вызывала всевозможные ограничения при приеме на службу или поступлении в вуз, а значит, у части бывших революционеров из дворян была весомая причина скрывать свое происхождение.

Анализ занятости революционеров до ссылки свидетельствует о том, что оппозиционным движением была охвачена прежде всего учащаяся молодежь, далее среднее или мелкое столичное чиновничество, потом учителя, а затем рабочие $-14 \%$ движения. Последний показатель также нельзя считать непогрешимым, так как попасть в категорию рабочих или «пролетариев» в 1920-1930 гг. было опять же выгоднее, чем оказаться в дворянском сословии.

Половина иркутских политических ссыльных (28 чел.) были отправлены в пределы губернии за организацию или активное участие в пропагандистской работе. Назовем здесь лишь некоторые имена. Это Н. И. Глушков, наказанный за членство «в противозаконном сообществе и распространение преступных сочинений»; участник общества «Сморгонь» в Петербурге Н. И. Гончаров; В. И. Зак, высланный за связи с делом о «лондонских пропагандистах»; Н. Е. Кузнецов, Х. З. Новаковский и Н. С. Обручников - участники Казанской демонстрации; Н. Н. Лопатин, двоюродный брат Г. Д. Лопатина, отправленный в ссылку за противоправительственную пропаганду в Петербурге; М. А. Натансон, руководитель кружка студентов Медико-хирургической академии, послужившего основой для общества «чайковцев»; студент той же академии С. Г. Стахевич; М. А. Рабинович, наказанный по делу о пропаганде в империи (процесс 193-х); Н. Ф. Цвиленев, осужденный на процессе 50-ти и некоторые др. ${ }^{6}$

В отличие от предыдущего десятилетия, давшего ссылке значительное количество теоретиков и идейных вдохновителей народнических организаций, в 1870-х гг. более заметное место на поселениях Иркутской губернии стали занимать «практики революции» - «бомбисты», члены террористических групп, организаторы диверсий против министров царского правительства, начальников жандармских округов, государственных чиновников различных рангов [10]. Среди сторонников леворадикальных формирований должны быть названы: нечаевцы Н. Н. Николаев, член «Народной расправы», участник убийства студента Иванова - Петропавловская волость Киренского округа, 1873 г. и А. М. Понич, высланный в 1879 г. по распоряжению одесского генерал-губернатора в Тунку; ишутинцы, члены группы «Ад» П. Д. Ермолов, после Нерчинской каторги поселенный в Киренске, затем в Якутске, 1871 г. и П. Ф. Николаев - Якутск, Верхоленск, Киренск, 1874 г.; по «Чигиринскому делу» - В. К. Дебогорий-Мокриевич, Тельма, 1879 г. и отставной солдат Ф. Д. Прядко, признанный виновным в подготовке восстания крестьян, 1877 г.; а также В.О. Избицкий, высланный в губернию за принадлежность к киевским террористам, 1879 г. и В. А. Панкратьев, обвинявшийся в «участии в приготовлении вместе с Н. С. Тютчевым убийства агента жандармского управления Беланова», Киренск, 1879 г. ${ }^{7}$

Средние сроки пребывания в ссылке были небольшими. Так, анализ 51-й биограммы дал следующие результаты: в совокупности в Иркутской ссылке (без учета ссылки дальнейшей, например, Якутской) революционеры провели 274 года, т. е. по 65 месяцев или более 5 лет каждый. Срок, на первый взгляд, и не такой удручающий. Однако чтобы сделать верные выводы из данного показателя, надо учитывать, что для немалой части этих людей иркутская ссылка была не первой, а также и то, что часть революционеров выходили на поселение в пределы губернии после про-

\footnotetext{
${ }^{6}$ Деятели революционного движения в России. Т. ІІ, вып. І. Стб. 271, 294, 438 ; вып. ІІ. Стб. 705, 808 ; вып. III. 1002, 1049, 1068, 1298 ; вып. IV. Стб. 1903.

7 Там же. Стб. 275, 329, 120-121, 276 ; т. II, вып. І. Стб. 338 ; вып. II. Стб. 510 ; вып. III. Стб. 1142, 1284.
}

\section{Baikal Research Journal}


должительной Нерчинской каторги. Таким образом, «невольными гостями Сибири» они оставались не менее 8-10 лет [11, с. 227-286]

В 1870-е гг. в иркутской политической ссылке начинают постепенно складываться и основные центры поселений (или колонии). Требования гласного полицейского надзора предусматривали порядок равномерного рассредоточения «политиков» по территории губернии и размещение их вдали от рабочих поселков, промышленных и уездных центров. Однако на практике колонии ссыльных возникали, скорее, вопреки этому правилу: главным мотивом в выборе места проживания у революционеров была возможность трудоустройства, потребность в применении своих профессиональных знаний и навыков, а также, что немаловажно, щадящие климатические условия.

В анализируемый период революционеров размещали во всех округах губернии, однако больше всего их было в селе Тунка Иркутского окружного полицейского управления - 16 ссыльных, или 27,9 \% от общего числа. Тунка этого времени - экономический и культурный центр Тункинской долины с населением в $2,5-3,0$ тыс. чел., с несколькими перерабатывающими заводиками и почтовой станцией. Обладая сравнительно мягким климатом, Тунка была весьма притягательным местом для политических ссыльных. В 1870-е гг. здесь были на поселении А. М. Apшавский, И. П. Баринов, Ф. В. Воробьев, В. И. Зак, Ф. Н. Левандовская, А. О. Лукашевич, М. В. Павловский, А. М. Понич, А. И. Савенко, И. Ф. Савенко, Н. Н. Смецкая, Е. Д. Субботина, Л. П. Третьяков, Р. Б. Туманова, З. З. Цыганков, Д. Н. Чуркин. В Тунке селили и польских ссыльных, в том числе священнослужителей [12, с. 373].

Второе место по численности размещенных политических ссыльных занимал Киренский полицейский округ - 13 чел., или $22,4 \%$, что и не удивительно, если брать во внимание его значительную территорию. Третье было у города Иркутска и Верхоленского округа - по 10 «политиков», и четвертое -9 чел. - у Балаганского. Таким образом, иркутские ссыльные размещались в основном на юге губернии, в уже хорошо обжитых районах, имеющих более мягкий климат. Однако следует иметь в виду, что, как правило, политические ссыльные неоднократно меняли места своего проживания. Это было связано с поиском работы или более выгодного места службы, с состоянием здоровья или с отъездом супруга (супруги) в другие места. Якутские и забайкальские ссыльные, окончившие сроки каторги или гласного надзора и получившие право приписаться к одному из крестьянских обществ, также стремились поселиться в пределах Иркутской губернии, выбирая местом жительства ближайшие к центру волости.

Ссыльные этого периода в массе своей были выходцами из состоятельных дворянских и купеческих семей и могли рассчитывать на помощь родственников из Европейской России. Однако среди них было и немало неимущих, живших и до ареста только своим трудом (учителя, врачи, мелкие и средние чиновники). Такие «политики», водворившись на поселение, вынуждены были искать средства к существованию, однако работу удавалось найти далеко не всем. По нашим подсчетам, лишь 16 из $58(27,6$ \% ) имели постоянный заработок. При этом четверо служили в частных заведениях (в основном, у местных купцов), трое - на золотых приисках, столько же занималось журналистикой, один - медицинской практикой и по одному - на строительстве дорог и на сельскохозяйственных работах.

Не все ссыльные мирились с перспективой многолетнего вынужденного пребывания в пределах Иркутской губернии. Для одних невыносимыми были суровые природно-климатические условия, другие не могли привыкнуть к жизни в иной культурно-бытовой и языковой среде коренных народов Восточной Сибири, третьи рвались в Европейскую Россию, чтобы в составе нелегальных организаций продолжить борьбу с самодержавным государством. В силу этих причин уже в 1860 и

\section{Baikal Research Journal}


1870 гг. в политической ссылке можно отметить и такое явление, как побеги с места поселения, из пересыльных тюрем и с этапов.

По нашим подсчетам, в 1860-е гг. из пределов Иркутской губернии был совершен лишь один побег, а в 1870-е гг. - уже шесть. На первый взгляд, кажется, что бежали единицы, однако в процентном отношении это выглядит иначе $-4,8$ и 10,4 \% соответственно, или 8,9 \% за весь период. Данное обстоятельство можно рассматривать уже как проявление тенденции, которая в 1880-е гг. переросла в настоящее явление, а в начале XX в. превратилась в характерную черту сибирской политической ссылки.

1860-е гг. из иркутской ссылки пытался бежать только О. А. Мотков - вольноотпущенный дворовый человек, принадлежавший к кружку Ишутина, судившийся Верховным судом за принадлежность к революционной организации "Ад». В 1870-х гг. из пределов Иркутской губернии бежали или пытались бежать: В. К. Дебогорий-Мокриевич - ночью на этапе он сделал «сменку» с уголовным Павлом Павловым (обменялся за вознаграждение паспортами) и в октябре 1879 г. под его именем был поселен в селе Тельминском, откуда в начале ноября бежал, пробыв в Сибири около года, и выехал в 1880 г. в Европейскую Россию; Ф. К. Долинин, в качестве административно-ссыльного был поселен в октябре 1879 г. в Киренске, затем бежал, но был пойман и выслан в Якутскую область; В. И. Зак, в июле 1879 г. скрылся из Иркутска, где работал в аптеке, бежал и был задержан в Балаганском округе, затем по распоряжению министра внутренних дел выслан под надзор в Верхоянск Якутской области; В. О. Избицкий, по дороге в ссылку в октябре 1879 г., обменявшись документами с уголовным Степановым, скрылся недалеко от Иркутска, но пропал без вести; Н. Н. Смецкая, в июне 1879 г. бежала из Тунки, была обнаружена в Балаганском округе и переведена в Якутскую область; Е. Д. Субботина, будучи водворена в Тунке, пыталась 28 января 1879 г. бежать, добралась до Иркутска, где и была задержана, а затем выслана в Верхоленск с учреждением особого надзора полиции.

Как видим, из семи побегов удачным оказался только один, что может быть объяснимо малочисленностью политических ссыльных (каждый - на виду) и отсутствием у революционеров должной организации по устройству побегов. Не следует забывать и то, что из Сибири в Европейскую Россию можно было попасть только Московским трактом, а железнодорожной магистрали, как известно, еще не существовало [13].

В 1860-1870-е гг. открывается мартиролог иркутской политической ссылки. Не все выдерживали тяжелые климатические и материально-бытовые условия. За данный период здесь умерло семь человек, что составляет $8,9 \%$ от общего числа отбывавших наказание: П. А. Мартьянов, 1865 г., Иркутская тюремная больница; О. А. Мотков - от чахотки, декабрь 1867 г.; Н. А. Серно-Соловьевич, февраль 1866 г.; А. П. Щапов, 1876 г.; И. А. Худяков, сентября 1876 г.; А. А. Яковлев, умерший от тифа; В. О. Избицкий, по предположению составителей словаря, убитый бродягами в тайге в 1879 г. [14].

Итак, иркутская политическая ссылка 1860-1870-х гг. (опять же без ссыльных поляков и высланных крестьян) была численно невелика. За первое десятилетие здесь побывало не более 30 революционеров, за второе - около 80-90 чел. Можно предположить, что на самом деле общее число ссыльных было несколько большим, но увеличение оказалось незначительным.

Политические ссыльные попадали в Иркутскую губернию после значительного тюремного заключения. В 1860 -е гг. среди революционеров преобладали осужденные в каторжные работы (12 из 21), которые они отбывали в основном в Нерчинском горном округе, а затем поселялись в Иркутской губернии, в 1870-х гг. - большинство «политиков» ссылались на поселение (49 из 58). В этот период начали складываться и колонии ссыльных - Иркутский, Киренский, Верхоленский и Балаганский полицейские округа.

\section{Baikal Research Journal}

электронный научный журнал Байкальского государственного университета 
Сравнительный анализ социального облика ссыльных двух десятилетий дает нам все-таки больше совпадений, чем отличий: ссылка была в основном уделом дворянской молодежи, среди которой выделялось много городских средних слоев - студентов, учащихся, служилой интеллигенции и чиновничества. Хорошо прослеживается при этом тенденция сравнительно быстрого возрастания (а с середины 1870-х гг. и некоторого преобладания) в ее составе разночинцев. Абсолютное большинство «шестидесятников» были сосланы в пределы губернии по приговорам судов, однако в 1870-х гг. среди иркутских ссыльных быстро увеличивается доля высланных административным порядком. Особенно эта тенденция становится заметной во второй половине десятилетия.

\section{Список использованной литературы}

1. Иркутский край. Четыре века: история Иркутской губернии (области) XVIIXXI вв. / А. В. Гимельштейн, Л. М. Дамешек, Ю. А. Зуляр [и др.]. - Иркутск : Востсибкнига, 2012. -800 c.

2. Бедулина И. П. История государственной архивной службы Иркутской области (19201938 годы) / И. П. Бедулина. - Иркутск : Оттиск, 2011. - 240 с.

3. Рощевская Л. П. История политических репрессий в царской России : учеб. пособие / Л. П. Рощевская. - Сыктывкар : Изд-во Сыктывк. гос. ун-та, 2006. - 140 с.

4. История Сибири с древнейших времён до наших дней : в 5 т. / под ред. А. П. Окладникова, В. И. Шункова. - Л. : Наука, Ленингр. отд-ние, 1968. - Т. 3 : Сибирь в эпоху капитализма. $-511 \mathrm{c.}$

5. Дворянов В. Н. В Сибирской дальней стороне ... (Очерки истории царской каторги и ссылки. 60-е годы XVIII в. - 1917 г.) / В. Н. Дворянов. - Минск : Наука и техника, 1971. - 374 с.

6. Троицкий Н. А. Безумство храбрых. Русские революционеры и карательная политика царизма 1866-1882 гг. / Н. А. Троицкий. - М. : Мысль, 1978. - 174 с.

7. Марголис А. Д. Тюрьма и ссылка в императорской России. Исследования и архивные находки / А. Д. Марголис. - М. : Лантерна : Вита, 1995. - 207 с.

8. Ленин В. И. Памяти Герцена // Полное собрание сочинений : в 55 т. / В. И. Ленин. 5-е изд. - М. : Политиздат, 1968. - Т. 21. - С. 255-264.

9. Ленин В. И. Роль сословий и классов в освободительном движении // Полное собрание сочинений : в 55 т. / В. И. Ленин. - 5-е изд. - М. : Политиздат, 1968. - Т. 23. - С. 397-401.

10. Троицкий Н. А. Царские суды против революционной России. Политические процессы 1871-1880 гг. / Н. А. Троицкий. - Саратов : Изд-во Сарат. ун-та, 1976. - 411 с.

11. Жуковский-Жук И. Мартиролог Нерчинской каторги / И. Жуковский-Жук // Кара и другие тюрьмы Нерчинской каторги : сб. воспоминаний, документов и материалов / под ред. А. Якимовой-Диковской, Э. В. Плескова. - М. : Всесоюз. О-во бывших политкаторжан и ссыльнопоселенцев, 1927. - С. 227-286.

12. Шостакович Б. С. Феномен польско-сибирской истории (XVII в. - 1917 г.). Основные аспекты современных научных трактовок и задач дальнейшей разработки темы / Б. С. Шостакович. - М. : МИК, 2015. - $752 \mathrm{c.}$

13. Побеги революционеров / сост. А. Зарин. - Л. : Вокруг света, 1928. - 124 с.

14. Пономарев Г. П. Мартиролог иркутской ссылки / Г. П. Пономарев // Иркутская ссылка : сб. Иркут. землячества. - М. : Всесоюз. О-во бывших политкаторжан и ссыльнопоселенцев, 1934. - С. 263-291.

\section{References}

1. Gimel'shtein A. V., Dameshek L. M., Zulyar Yu. A. et al. Irkutskii krai. Chetyre veka: istoriya Irkutskoi gubernii (oblasti) XVII-XXI vv. [Irkutsk region. Four centuries: history of the Irkutsk province (area) of the 17-21st centuries]. Irkutsk, Vostsibkniga Publ., 2012. 800 p.

2. Bedulina I. P. Istoriya gosudarstvennoi arkhivnoi sluzhby Irkutskoi oblasti (19201938 gody ) [History of the public archival service of the Irkutsk region (1920-1938)]. Irkutsk, Ottisk Publ., 2011. 240 p.

3. Roshchevskaya L. P. Istoriya politicheskikh repressii v tsarskoi Rossii [History of political repressions in tsarist Russia]. Syktyvkar State University Publ., 2006. 140 p.

4. Okladnikov A. P., Shunkov V. I. (eds). Istoriya Sibiri s drevneishikh vremen do nashikh dnei [History of Siberia from ancient times till our days]. Leningrad, Nauka Publ., 1968. Vol. 3. 511 p.

\section{Baikal Research Journal}


5. Dvoryanov N. V. V sibirskoi dal'nei storone. Ocherki istorii tsarskoi katorgi i ssylki. 60-e gody XVIII v. $-1917 \mathrm{~g}$. [On the far side of Siberia. Short notes on penal servitude and exile in 1760-1917]. Minsk, Nauka Publ., 1971. 374 p.

6. Troitskii N. A. Bezumstvo khrabrykh. Russkie revolyutsionery i karatel'naya politika tsarizma 1866-1882 gg. [Folly of spirited people. Russian revolutionaries and penal policy of tsarism in 1966-1889 Moscow, Mysl' Publ., 1978. 174 p.

7. Margolis A. D. Tyur'ma i ssylka v imperatorskoi Rossii. Issledovaniya i arkhivnye nakhodki [Prison and exile in imperial Russia. Research studies and archive findings]. Moscow, Lanterna Publ., Vita Publ., 1995. 207 p.

8. Lenin V. I. In memory of Herzen. Polnoe sobranie sochinenii [Complete Works]. $5^{\text {th }}$ ed. Moscow, Politizdat Publ., 1968, vol. 21, pp. 255-264. (In Russian).

9. Lenin V. I. Role of estates and classes in liberation movement. Polnoe sobranie sochinenii [Complete works]. $5^{\text {th }}$ ed. Moscow, Politizdat Publ., 1968, vol. 23, pp. 397-401. (In Russian).

10. Troitsky N. A. Tsarskie sudy protiv revolyutsionnoi Rossii. Politicheskie protsessy 18711880 gg. [Tsarist courts against revolutionary Russia. Political processes in1871-1880 ]. Saratov State University Publ., 1976. 411 p.

11. Zhukovskii-Zhuk I. Martyrology of Nerchinsk hard labor camp. In Yakimova-Dikovskaya A., Pleskov E. V. (eds). Kara i drugie tyur'my Nerchinskoi katorgi. Sbornik vospominanii, dokumentov $i$ materialov [Kara and other prisons of the Nerchinsk hard labor camp. Collection of memoirs, documents and materials]. Moscow, All-Russian Society of Society of Political Hard Laborers and Deportees Publ., 1927, pp. 227-286. (In Russian).

12. Shostakovich B. S. Fenomen pol'sko-sibirskoi istorii (XVII v. - 1917 g.) Osnovnye as pekty sovremennykh nauchnykh traktovok i zadach dal'neishei razrabotki temy [Phenomenon of Pole-Siberian history (XVII-th century - 1917). Main aspects of modern scientific interpretations and tasks of further development of the topic]. Moscow, MIK Publ., 2015. $752 \mathrm{p}$.

13. Zarin A. (eds). Pobegi revolyutsionerov [Prison breaking of revolutionaries]. Leningrad, Vokrug sveta Publ., 1928. 124 p.

14. Ponomarev P. Martyrology of Irkutsk Exile. In Bustrem V. V. (ed.) Irkutskaya ssylka: sbornik irkutskogo zemlyachestva [Irkutsk Exile: Collection of Irkutsk Community]. Moscow, All-Russian Society of Society of Political Hard Laborers and Deportees Publ., 1934, pp. 263-291. (In Russian).

\section{Информация об авторах}

Иванов Александр Александрович - доктор исторических наук, профессор, кафедра политологии, истории и регионоведения, Иркутский государственный университет, 664003, г. Иркутск, ул. К. Маркса, 1, e-mail: ottisk@irmail.ru.

Мясников Дмитрий Александрович - кандидат исторических наук, старший преподаватель, кафедра политологии, истории и регионоведения, Иркутский государственный университет, 664003, г. Иркутск, ул. К. Маркса, e-mail: mda80@yandex.ru.

\section{Authors}

Alexander A. Ivanov - Doctor habil. (History), Professor, Chair of Politology, History and Regional Studies, Irkutsk State University, 1 K. Marx St., 664003, Irkutsk, Russian Federation; e-mail: ottisk@irmail.ru.

Dmitry A. Myasnikov - PhD in History, Senior Lecturer, Chair of Politology, History and Regional Studies, Irkutsk State University, 1 K. Marx St., 664003, Irkutsk, Russian Federation; e-mail: mda80@yandex.ru.

\section{Библиографическое описание статьи}

Иванов А. А. Структура и численность политической ссылки Иркутской губернии 1870-х годов / А. А. Иванов, Д. А. Мясников // Baikal Research Journal. - 2016. — T. 7, № 4. — DOI : 10.17150/2411-6262.2016.7(4).19.

\section{Reference to article}

Ivanov A. A., Myasnikov D. A. Structure and size of political exile in Irkutsk Province in the 1870s. Baikal Research Journal, 2016, vol. 7, no. 4. DOI : 10.17150/2411-6262.2016.7(4).19. (In Russian).

\section{Baikal Research Journal}

